\title{
Effectiveness of Scientific Blended Learning-Product Oriented Against Student Competency Enhancement
}

\author{
Muhammad Amin ${ }^{1}$ and Asahan Pasaribu ${ }^{1}$ \\ \{ aminunimed@unimed.ac.id, a.pasaribu@gmail.com \} \\ Faculty of Engineering, Universitas Negeri Medan, Indonesia ${ }^{1}$
}

\begin{abstract}
This study aims to determine the effectiveness of using Scientific Blended Learning - Product Oriented (SBL-PO). The effectiveness of learning is measured by increasing the ability of soft skills and student learning outcomes from the aspects of knowledge and skills in the lecture process. This study uses a quasi-experimental method. Data collection techniques used observation sheets, questionnaires, and assessment sheets. Data analysis was performed with descriptive and quantitative statistics. Quantitative analysis was carried out by different tests of the Wilcoxon Signed Ranks Test and the Kruskal Wallis Test. The results of the study show that SBL-PO has proven effective in improving the ability of soft skills and student learning outcomes. This is evident from the student's soft skills ability to increase significantly $(\mathrm{p}=0,000)$ at each meeting. Improved student learning outcomes also proved significantly $(\mathrm{p}=0.014)$ better after using the SBL-PO learning model compared to before using the SBL-PO learning model.
\end{abstract}

Keywords: Scientific, blended learning, product oriented, ability of soft skills, student competency

\section{Introduction}

Higher education as a formal education institution aims to improve intelligence, knowledge, personality, noble character, and skills so that the graduates can live independently and practice the knowledge they have acquired. Therefore, universities as producers of human resources have a heavy responsibility in equipping graduates that they produce in entering the workforce. Global competition is currently very tight in all fields, so universities are very interested in maintaining the quality of their graduates as a necessity in maintaining their image and competitiveness in facing the world of work and industry.

Efforts made to improve the ability of students in higher education, especially for prospective teachers, are always organized and directed at various relevant learning goals such as: (1) learning to believe and devote to God Almighty, (2) learn to know (learning to know), (3) learning to do, (4) learning to live among each other side by side (learning together), and (5) learning to form identity (learning to be). Based on the goals and objectives of the study, the UNIMED Engineering Faculty graduates are expected to master the subject matter both theoretically and practically, which is certainly inseparable from the role of the lecturer who teaches in the classroom. 
Development, capacity building, and student learning capacity have always been a concern for managers and lecturers in producing the quality of relevant graduates, so as to produce prospective professional educators with a nuanced nuance in the era of globalization with competency and Indonesian-ness who can win global competition. It should be understood that in the current technological era it is characterized by a shift in the mind set from the linear-mechanistic to the synthetic mind set (creative thinking), followed by the emergence of new cultural traits. Therefore, to realize a quality generation it is necessary to do proactive efforts by fixing the learning system in the Teacher Education Institution which will produce qualified teacher candidates who are able to demonstrate their capacity and capability to compete with prospective teachers from other countries.

Based on these conditions, it is imperative that efforts to change the orientation and learning objectives carried out by the Educational Institution whose paradigm is TCL (Teaching Centre Learning) lead to SBL (Student Based Learning), in order to produce qualified graduates of prospective teachers. SBL is an approach that uses more learning methods/strategies that place students as active/ independent subjects/learners, with psychological conditions as adult learners, fully responsible for their learning, and able to learn beyond the classroom. With these principles, students are expected to possess and live the soul of a long-life learner and to master the hard skills and soft skills that support each other. Other conditions, the lecturers will switch functions to become facilitators, including as learning partners, and no longer as a primary knowledge source.

Along with the development of information technology, as well as the availability of supporting facilities, it is very necessary to have learning innovations that make it easier for students to use available e-learning facilities, so that student acquisition is more optimal [1]. Learning innovations that are considered very relevant are the application of blended learning that combines online learning with face-to-face learning, by controlling the acquisition of product-based lectures.[2][3] shows that the use of blended learning will provide benefits such as: (1) Optimizing the use of internet facilities in the overall learning process), (2) Optimizing the use of learning time for students, (3) Facilitating and expanding communication media between students with lecturers, and (4) Optimizing student learning achievement. Based on these conditions, it is very necessary to find ways to implement population-based blended learing that is effective in increasing students' ability to achieve the determined learning outcome.

[4] Describes blended learning as It represents an opportunity to integrate the innovative and technological advances offered by online learning and participation offered in the best of traditional learning. [5] States that blended learning is a learning model that combines face-toface learning and online learning. Often with the development of scientific implementation in the learning process, it is very relevant if blended learning is combined with scientific learning, because scientific is able to direct students to dig up information through observation, asking questions, experimenting, then processing data or information, presenting data or information, followed by analyzing, reasoning, then concluding, and creating, so that it is also very relevant to produce products [6][7]. Product oriented learning makes learning centered on students, involving science process skills in constructing concepts, laws or principles, capable of involving potential cognitive processes in stimulating the development of the intellect, especially the high-level thinking skills of students. 


\section{Methodology}

This research was initiated by Research and Development ( $R$ \& D) research which aims to develop product-oriented blended learning models and devices. The research model was adapted from Thiagarajan, Semmel, and Semmel in Trianto (2013: 189), namely the development of Four-D Models. The Four-D model consists of 4 stages of development, namely: define, design, develop, and desseminate or adapted to a 4-P model, namely (1) Defining which includes the front end analysis, student analysis, task analysis, concept analysis, and the formulation of learning objectives. (2) Design (Design) which includes the preparation stage of the benchmark reference test, the stage of media selection, format selection. (3) Development includes device validation by experts followed by revisions, simulations, limited trials with real students. (4) Disseminate stage is the stage of the use of devices that have been developed on a wider scale. At this final stage, the quasi-experimental method is used to determine the effectiveness of the use of the model found.

Data collection techniques in this study used instruments in the form of questionnaires, interview guidelines and documentation on development activities, and used test instruments on model effectiveness testing activities. The data analysis technique used in this study is a different test and explained by simple qualitative descriptive analysis techniques.

\section{Result and Discussion}

The findings of the model used include the Lecture Planning Activity model, and the learning implementation model. The results of the needs analysis in the initial activities indicate that product-oriented blended learning requires comprehensive planning related to mechanisms, facility readiness, learning resources, and commitment between students and lecturers [8]. Thus in general the steps developed in planning product oriented blended learning activities as shown in Figure 1. 


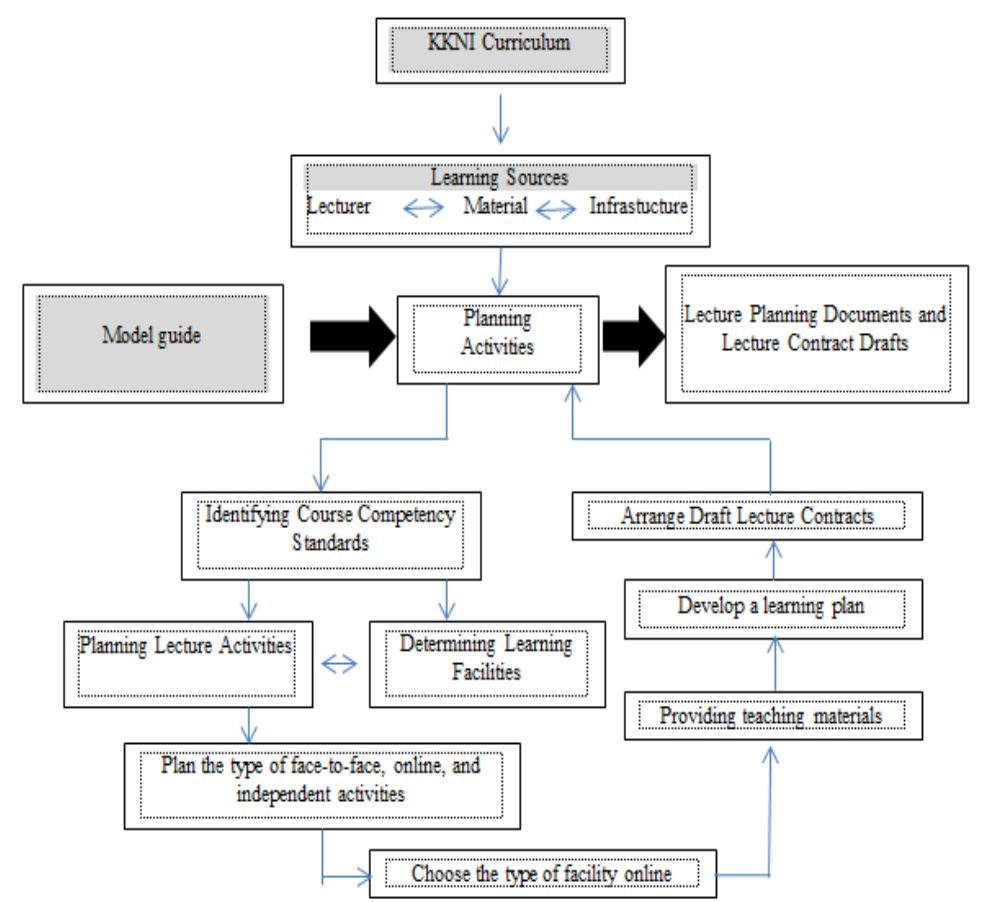

Fig. 1. Blended Learning Plan

In developing learning both by applying Blended Learning and conventionally, lecturers need to develop appropriate learning steps in a learning implementation plan based on the basic competencies that are to be achieved in learning. The development of learning steps that apply Blended Learning also needs to be well designed, based on the steps outlined in the planning section so that in the implementation of learning students do not feel technically difficult. Therefore, lecturers need to prepare everything needed, such as the materials that will be delivered or discussed, the platform that will be used in learning with Blended Learning, platform use tutorials used in learning by applying Blended Learning and so on. Before implementing learning by applying Blended Learning, lecturers must prepare all their learning needs, especially the use of technology platforms that will be used in learning that will be used without carrying out face-to-face.

Several platforms that can be used in learning with Blended Learning in accordance with selected types of on-line media, such as Group Miling Lists (Mailing Lists, such as Yahoo groups, Google+, and Google classroom), Web Blog Teachers, Social Media (Facebook, Twitter, Instagram, Path, etc.), Learning Management Systems or LMS Applications (such as Moodle, Edmodo, Quipper, Kelase, etc.) and so on. Next, how the platforms that have been determined by the lecturer are applied in learning beforehand in advance in the learning steps designed.

Based on the results of the needs analysis, and a description of the planning steps and types of lecture activities that allow it to be done online and face to face, then in the context of lectures by combining the application of six class assignments, the lecture activities can be described as shown in Figure 2. 


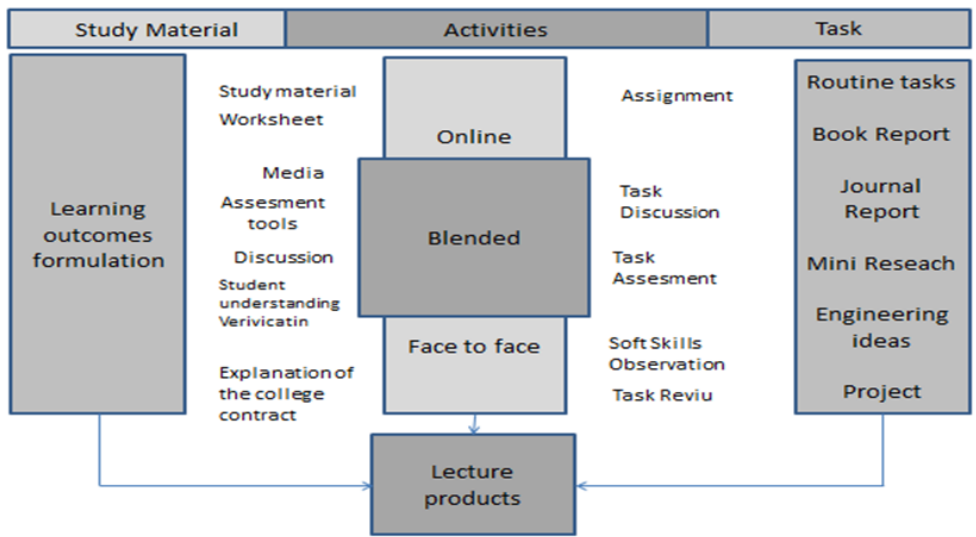

Fig. 2. Model Implementation of Product Oriented Learning Activities

The developed model equipped with standards or provisions relating to the use of models in each course. The terms of the use of the model, consisting of interrelationships with the Quality Standards of Planning, Learning, quality standards for the implementation of lectures, and standards of monitoring and evaluation.

The provisions relating to the Learning Planning Quality Standards consist of: (1) Lecturers planning blended learning which are prepared based on scientific learning principles compiled in the Lecture Program Unit, (2) Lecturers arrange teaching materials and socialize to students through lecturer blogs, (3) Lecturers are able to choose the most suitable learning method to achieve the desired outcome (product) of learning, (4) Learning resources are provided according to the learning objectives, and (5) Learning facilities and infrastructure can support learning. This condition will create a learning process that can be done by students and lecturers not limited by time and place [9]; [10].

Furthermore, the provisions governed by Learning Implementation Standards include: (1) Lecturers must be disciplined in carrying out learning, both online and classroom learning, (2) Students must be actively involved, both online and face-to-face, so that they are created interactions that support learning, (3) Lecturers must be exemplary pedagogically, personally, socially, and professionally in the face-to-face learning process applied must be able to develop learners as much as possible, (6) Learning facilities and infrastructure must be used optimally, (7) Learning methods must direct students to study independently or in groups, (8) Lecturers are able to develop and use various teaching media, (9) Learning resources can be accessed by interested parties, and (10) Administration of learning support activities carried out in a transparent and accountable manner [2].

While the standards regulated in Monitoring and Evaluation activities include: (1) Learning outcomes assessment is carried out transparently, (2) Evaluation of learning must be able to measure achievement of competence, conscience, and compasion, (3) Lecturers utilize feedback from students to improve the learning process , (4) Lecturers and students reflect on the learning process for continuous improvement, and (5) The learning process is evaluated in each face-to-face activity, (6) Every lecturer must develop and provide assignments consisting of routine assignments, critical book report, review journal, mini research, engineering ideas, and projects in order to evaluate learning outcomes and to improve students' learning abilities and experiences, (7) Each task is corrected, discussed and / or returned to students as feedback on the process and results of learning through selected media channels, and (8) the minimum 
number of assignments given ha should be adjusted to the credit load and planned in the learning plan.

The use of product-oriented blended learning models, in addition to being expected to be able to improve students' soft skills, is also expected to improve student learning outcomes. Therefore, one indication of the effectiveness of the use of the model is the increase in student learning outcomes, in addition to the improvement of soft skills. To see an increase in student learning outcomes on the use of models in subjects that are the subject of research, learning outcomes data are needed on the application of models and data on student learning outcomes in the same subject and the same lecturer before using the model.

Student learning outcomes data obtained from the results of the application of the model is the average score of student learning outcomes on subjects that are the subject of research trials that take place in odd semester. While the data on student learning outcomes before the application of the model is the data on learning outcomes for the same subjects as the subject subjects, taken care of by the same teaching team, and took place in the previous year. The student learning outcomes data analyzed are the final values derived from the accumulation of formative values from one to the value of students obtained in formative four for each group of subjects. The average score of learning outcomes in both groups of subjects before and after the application of the model is summarized in Table 1.

Table 1. Summary of Student Learning Outcomes Before and After Model Application

\begin{tabular}{cccc}
\hline No & $\begin{array}{c}\text { Courses } \\
\text { code }\end{array}$ & $\begin{array}{l}\text { Average Score } \\
\text { Before Model } \\
\text { Application }\end{array}$ & $\begin{array}{l}\text { Average Score } \\
\text { After Model } \\
\text { Application }\end{array}$ \\
\hline 1 & A1 & 81.79 & 88.95 \\
2 & A2 & 80.22 & 81.35 \\
3 & A3 & 81.19 & 82.65 \\
4 & B1 & 74.14 & 83.81 \\
5 & B2 & 77.08 & 81.99 \\
6 & B3 & 81.81 & 88.76 \\
\hline
\end{tabular}

Based on the data, it can be seen that student learning outcomes in the B1 and B2 subject groups before using the blended learning model are relatively low (74.14) and (77.08), and after the application of the model the learning outcomes are much better. The B1 and B2 subject groups are courses that are in the first semester, so students who take this course really need guidance to adjust. The use of the blended learning model, at each meeting will be given orientation and reflection as part of the learning approach that serves to give direction to learning, so that students will be able to adjust in the face of lectures. Data comparison of learning outcomes B1 and B2 between before and after the application of the model shows that the application of the learning model greatly helps students to adjust quickly so they are able to obtain better learning outcomes.

To find out whether student learning outcomes in each group of subjects after the application of the learning model are better than before the implementation of the model, it is necessary to do the testing with different tests. The summary of the results of the different test after $(\mu 1)$ and before $(\mu 2)$ the application of the model is shown in Table 2.

The test results showed that all subjects that were the subjects of the study gave different student learning outcomes after the use of the model compared to before using the model. Based on the average data of learning outcomes shows that the average student learning outcomes after the use of the model is higher when compared with the average student 
learning outcomes before the use of the model. Thus, student learning outcomes are better after the use of the model when compared to before using the model. This provides an indication that the use of blended models effectively improves student learning outcomes.

Table 2. Summary of Different Test Results After $(\mu 1)$ and Before $(\mu 2)$ Application of the Model

\begin{tabular}{|c|c|c|c|c|}
\hline No & Courses code & $\chi^{2}$ count & $\chi^{2}$ Table & Decison \\
\hline 1 & $\mathrm{~A} 1$ & 20,83 & 3,84 & different \\
\hline 2 & A2 & 4,17 & 3,84 & different \\
\hline 3 & A3 & 4,00 & 3,84 & different \\
\hline 4 & B1 & 18,18 & 3,84 & different \\
\hline 5 & B2 & 8,91 & 3,84 & different \\
\hline 6 & B3 & 6,00 & 3,84 & different \\
\hline
\end{tabular}

Furthermore, the observation activities on improving the ability of soft skills that are targeted at the research activities are carried out in three stages according to the implementation cycle of formative activities. Observation activities were carried out on six subjects that were targeted by the study. The recapitulation of the overall observations is shown in Table 3.

Tabel 3. Recapitultion of Student Soft Skills Obsevation

\begin{tabular}{|c|c|c|c|c|c|c|c|c|}
\hline \multirow{2}{*}{ No } & \multirow{2}{*}{ Petemuan } & \multicolumn{6}{|c|}{ Mata Kuliah } & \multirow{2}{*}{ Rata-rata } \\
\hline & & A1 & A2 & A3 & B1 & B2 & B3 & \\
\hline 1 & Pertemuan 4 & 1,34 & 1,26 & 1,22 & 1,20 & 1,21 & 1,32 & 1,26 \\
\hline 2 & Pertemuan 5 & 1,50 & 1,42 & 1,40 & 1,38 & 1,38 & 1,49 & 1,43 \\
\hline 3 & Pertemuan 6 & 1,67 & 1,59 & 1,55 & 1,54 & 1,54 & 1,66 & 1,59 \\
\hline 4 & Pertemuan 7 & 1,85 & 1,77 & 1,74 & 1,73 & 1,72 & 1,84 & 1,77 \\
\hline 5 & Pertemuan 8 & 1,97 & 1,91 & 1,93 & 1,89 & 1,89 & 2,00 & 1,93 \\
\hline 6 & Pertemuan 9 & 2,13 & 2,07 & 2,08 & 2,06 & 2,04 & 2,16 & 2,09 \\
\hline 7 & Pertemuan 10 & 2,28 & 2,24 & 2,22 & 2,23 & 2,21 & 2,33 & 2,25 \\
\hline 8 & Pertemuan 11 & 2,44 & 2,41 & 2,39 & 2,40 & 2,38 & 2,49 & 2,42 \\
\hline 9 & Pertemuan 12 & 2,60 & 2,58 & 2,56 & 2,57 & 2,54 & 2,66 & 2,58 \\
\hline 10 & Pertemuan 13 & 2,77 & 2,75 & 2,74 & 2,73 & 2,71 & 2,81 & 2,75 \\
\hline 11 & Pertemuan 14 & 3,15 & 3,15 & 3,17 & 3,13 & 3,14 & 3,18 & 3,15 \\
\hline \multirow[t]{2}{*}{12} & Pertemuan 15 & 3,31 & 3,33 & 3,35 & 3,27 & 3,33 & 3,37 & 3,33 \\
\hline & Rata-rata & 2,25 & 2,21 & 2,20 & 2,18 & 2,17 & 2,28 & \\
\hline
\end{tabular}

Based on the data in Table 3, it can be seen that the average ability of the students' soft skills observed has increased in each meeting. Increasing the ability of soft skills at each meeting reached an average of $9.28 \%$. If the observation results are reviewed in each formative cycle, then the average increase in soft skills ability in the second cycle to the third cycle is $30.51 \%$ (from an average of 1.51 to 2.17 ), and in the third cycle to the fourth cycle reached $26.47 \%$ (from an average of 2.17 to 2.95 ). The increase in the score of soft skills ability also looks significant based on the results of the Kruskal-Wallis Test with Chi Square. Based on the results of the test with the help of the SPSS program, it shows that the Chi Squre value is 71.42, while the Chi Square value of the table is 19.7. These results indicate that the value of itung 2 count $>\chi 2$ tables, thus the average score of soft skills obtained by students at each meeting is significantly different.

Based on the profiles of the two groups of subjects in improving the ability of the students 'soft skills, it was seen that each of the subjects in the two groups of subjects had similarities in improving the abilities of students' soft skills. The results of different test scores on the 
average skills of soft skills produced from the two groups of subjects show that the value of the probability of acceptance (Asymp. Sig) is obtained at 0.97 , and the acceptance value specified is 0.05 . This means that the probability value is $>0.05$, which means that the average score of the students' soft skills produced from the two groups of subjects does not have a significant difference. These results also prove that all subjects who are the subjects of research have similarities in developing the ability of students' soft skills, without having to distinguish between educational groups or study groups.

\section{Conclusion}

Based on the results of the study concluded that the results of the effectiveness test show that the scientific model of blended learning is product oriented, effectively improving student learning outcomes. Based on the analysis of student learning results indicate a significant increase between learning before using the model with after using the model. This result shows that the average student learning outcomes are better when compared to the average student learning outcomes before using the learning model. The results of observations on the ability of student soft skills also showed a significant increase, where the average increase of each meeting reached $9.28 \%$. The improvement in the ability of soft skills for students does not differ between courses that are followed by students (See Table 3).

\section{References}

[1] Rusman, D. Kurniawan, and C. Riyana, Pembelajaran Berbasis Teknologi Informasi dan Komunikasi. Bandung: Rajawali Pers, 2011.

[2] Lalima and K. L. Dangwal, "Blended Learning: An Innovative Approach," Univers. J. Educ. Res., vol. 5, no. 1, pp. 129-136, 2017.

[3] Husamah, Pembelajaran Bauran (Blended Learing). Malang: Prestasi Pustaka, 2014.

[4] K. Thorne, Blended learning: How to integrate online and traditional learning. Sterling VA: Kogan Page Limited, 2003.

[5] D. R. Garrison and N. D. Vaughan, Blended Learning in Higher Education: Framework, principles and guidelines. San Fransisco: Josey-Bass, 2008.

[6] A. W. M. Hoogveld, F. Paas, and W. M. G. Jochems, "Training higher education teachers for instructional design of competency-based education: Product-oriented versus process-oriented worked examples," Teach. Teach. Educ., vol. 21, pp. 287-297, 2005.

[7] Y. Zhao, The Take-Action Guide to World Class Learners Book 2. Thousand Oaks, CA: Corwin, 2016.

[8] I. E. Allen and J. Seaman, "Changing course: Ten years of online education in the United States," Babson Park MA Babson Surv. Res. Gr. Quahog Res. Group, LLC., 2013.

[9] N. Suryani, "Improving Quality of Learning at University Through Application of Blended Learning: a Case Study at Sebelas Maret University, Solo, Indonesia," Int. J. Educ. Res., vol. 1, no. 6, pp. 1-12, 2013.

[10] Y. L. Ningsih, "Aplikasi Blended Learning pada Pembelajaran Kalkulus 1 di Universitas PGRI Palembang," J. Dosen Univ. PGRI Palembang, 2016. 